\title{
Perancangan Fasilitas Kerja Ergonomis pada Stasiun Persiapan Menggunakan Analisis Virtual Environment Modelling
}

\author{
Ade Hilman Fajar*, Yanti Sri Rejeki \\ Prodi Teknik Industri, Fakultas Teknik, Universitas Islam Bandung, \\ Indonesia. \\ *hilmanfajar123@gmail.com, ysr2804@gmail.com
}

\begin{abstract}
Environmental aspects and work postures in the company need to be considered in the garment industry. This is because the garment industry still relies heavily on human labor, and the work is generally repetitive and monotonous. CV. $\mathrm{X}$ is a company that produces various kinds of clothing ranging from children's clothing to adults. The number of operator errors in grouping at the preparatory work station resulted in the company often not achieving its production targets. Error grouping can be caused by fatigue experienced by the operator due to work postures that are not yet ergonomic. The grouping work process is carried out with a bent sitting posture without a base with the position of the material not being neatly arranged. This posture is not natural so that it can cause musculoskeletal complaints. Complaints were identified using a Nordic Body Map (NBP) questionnaire and a Posture Evaluation Index (PEI) work risk assessment was carried out through the creation of a Virtual Environment Modeling. The results of the questionnaire showed complaints on the neck, wrists, lower back, buttocks, and thighs. The work risk is in the activity of grouping and transferring the results of grouping. The PEI value is obtained in the range of $2.6-3.01$. This value is categorized as high because it is close to the maximum PEI value of 3.42. The design of the facility is a grouping table using the Anthropometric approach. PEI value after ergonomics facility modeling is obtained in the range of 1-1.6. These results indicate a reduction in the level of risk and increase operator comfort in doing work.
\end{abstract}

Keywords: Virtual Environment, NBP, PEI, Antropometri.

Abstrak. Aspek lingkungan serta postur kerja diperusahaan perlu diperhatikan pada industri garmen. Hal tersebut dikarenakan industri garmen masih banyak mengandalkan tenaga manusia, dan umumnya pekerjaan yang dilakukan repetitive dan monoton. CV. X merupakan perusahaan yang memproduksi berbagai macam pakaian dari mulai pakaian anak hingga dewasa. Banyaknya kesalahan operator dalam mengelompokkan pada stasiun kerja persiapan mengakibatkan perusahaan seringkali tidak mencapai target produksinya. Kesalahan pengelompokan dapat disebabkan oleh kelelahan yang dialami operator dikarenakan postur kerja yang belum ergonomis. Proses kerja pengelompokan dilakukan degan postur duduk membungkuk tanpa alas dengan posisi bahan yang belum tertata rapi. Postur tersebut tidak alamiah sehingga dapat menyebabkan keluhan musculoskeletal. Dilakukan identifikasi keluhan menggunakan kuesioner Nordic Body Map (NBP) dan penilaian risiko kerja Posture Evaluation Index (PEI) melalui pembuatan Virtual Environment Modelling. Hasil kuesioner menunjukkan keluhan pada leher, pergelangan tangan, punggung bawah, bokong, dan paha. Risiko kerja terdapat pada aktivitas pengelompokan dan pemindahan hasil pengelompokan. Diperoleh nilai PEI pada rentang 2,6-3,01. Nilai tersebut dikategorikan tinggi karena mendekati nilai maksimal PEI yaitu 3,42. Perancangan fasilitas berupa meja pengelompokan menggunakan pendekatan Antropometri. Nilai PEI setelah dilakukan pemodelan fasilitas ergonomis didapatkan pada rentang 11,6. Hasil tersebut menunjukkan adanya pengurangan tingkat risiko dan menambah kenyamanan operator dalam melakukan pekerjaan.

Kata Kunci: Virtual Environment, NBP, PEI, Antropometri. 


\section{A. Pendahuluan}

Produktivitas dapat ditingkatkan melalui pemberdayaan manusia yang baik diperusahaan salah satunya yaitu dengan memberikan lingkungan pekerjaan yang baik pada karyawan (Bioenergi Center, 2016). Hal tersebut perlu dilakukan karena lingkungan kerja hingga postur kerja yang kurang baik dapat berpengaruh pada performasi kerja sehingga menurunkan produktivitas kerja perusahaan (Tarwaka, 2015). Aspek lingkungan dan sikap kerja dalam pekerjaan juga penting diperhatikan salah satunya pada industri garmen. Industri garmen banyak mengandalkan tenaga manusia, dan umumnya pekerjaan yang dilakukan adalah repetitive (berulang) dan monoton dimana hal tersebut dapat menimbulkan banyak gangguan pekerjaan pada pekerja (Dragicevic et al., 2002).

CV. X adalah perusahaan yang bergerak pada bidang industri garmen. Perusahaan membuat berbagai macam pakaian dari baju anak hingga baju dewasa. Perusahaan beroperasi mulai pukul 07.00 sampai 16.00. Lini produksi perusahaan memiliki empat line produksi yang memiliki target produksi per hari 200 hingga 400 pcs produk per harinya. Data produksi pada bulan Februari 2020 menunjukkan bahwa setiap line produksi di perusahaan seringkali tidak mencapai target yang ditetapkan. Akibatnya, hal tersebut menjadi beban tambahan bagi pekerja karena harus lembur untuk memenuhi target produksinya.

Hasil observasi diperusahaan menemukan fenomena dimana operator sewing sering menemukan komponen-komponen bahan jahit yang tidak memiliki kelengkapan dan tidak sesuai dengan ukuran pasangannya. Hal tersebut mengakibatkan operator sewing harus menunggu bahan untuk dilengkapi dan diperbaiki terlebih dahulu. Kesalahan ini merupakan bagian dari tugas stasiun kerja persiapan karena bahan jahit pada stasiun kerja sewing dikirim dari stasiun kerja persiapan bagian pengelompokan. Operator pengelompokan bekerja repetitive mengelompokan bahan dengan posisi duduk tanpa alas dengan posisi bahan yang belum tertata rapi. Posisi pekerjaan tersebut tentu memerlukan keteletian dan konsentrasi yang lebih sehingga hal tersebut dapat menjadi peluang adanya kesalahan-kesalahan yang dilakukan operator saat melakukan pengelompokan. Selain itu pekerjaan repetitive dengan posisi kerja duduk statis tanpa alas dalam waktu yang lama akan menimbulkan keluhan musculoskeletal dan kelelahan pada pekerja (Widiastuti, 2005 dalam Pradnyawati, Tunas, \& Yudha, 2017). Kelelahan dan keluhan musculoskeletal dapat mengakibatkan hilangnya konsentrasi akibat keluhan yang diarasakan sehingga dapat menurunkan kinerja dan menambah kesalahan kerja pada pekerja (Pradnyawati, Tunas, \& Yudha, 2017). Maka postur pekerjaan sangat berpengaruh terhadap hasil pekerjaan sehingga postur aktivitas harus lebih ergonomis untuk mengurangi kelelahan pada operator (Tamara, Achiraeniwati, \& Rezeki, 2018).

Penelitian yang dilakukan berupa pengukuran risiko kerja operator serta merancang fasilitas kerja yang sesuai dengan keterbatasan manusia (ergonomis). Hal tersebut diharapkan dapat meminimasi kesalahan-kesalahan operator dan mengurangi risiko cidera akibat sistem kerja yang belum ergonomis. Penelitian dilakukan melalui pemodelan virtual environment modelling dan menghitung nilai Postur Evalutaion Index (PEI) untuk mengetahui tingkat risiko kerja dan kenyamanan operator dalam bekerja. Dilakukan juga penyebaran kuesioner Nordic Body Map untuk mengetahui keluhan apa saja yang dirasakan pada saat dan setelah melakukan pekerjaan dan perancangan fasiliitas dilakukan melalui pendekatan antropometri. Maka dapat rumuskan masalah sehingga didapatkan tujuan penelitian sebagai berikut:

1. Mengidentifikasi keluhan yang dirasakan operator pada stasiun kerja persiapan bagian pengelompokan.

2. Mengukur risiko kerja saat ini pada stasiun kerja persiapan bagian pengelompokan

3. Membuat rancangan fasilitas stasiun kerja persiapan bagian pengelompokan untuk mengurangi risiko kerja dan kesalahan pada operator.

\section{B. Metodologi Penelitian}

\section{Antopometri}

Anthropometri berasal dari kata "anthro" yaitu manusia dan "metri" yaitu ukuran. Antropometri didefinisikan sebagai kajian studi yang berhubungan dengan dimensi dan pengukuran pada anggota tubuh manusia (Wignjosoebroto, 2006). Manusia memiliki ukuran 
yang berbeda satu sama lainya. Anthropometri mengkaji secara luas mengenai perbedaan tersebut sehingga dijadikan bahan pertimbangan dalam membuat perancangan fasilitas kerja yang ergonomis. Data antropometri yang didapatkan dapat diterapkan secara luas pada beberapa perancangan sistem kerja diantaranya (Wignjosoebroto, 2006):

a) Perancangan produk.

b) Perancangan areal kerja.

c) Perancangan lingkungan kerja fisik.

d) Produk konsumtif

e) Perancangan fasilitas kerja.

Data antropometri yang didapatkan dapat menentukan ukuran serta bentuk rancangan produk yang sesuai dengan keterbatasan manusia sebagai penggunanya.

\section{Virtual Environment}

Virtual environment merupakan penggambaran suatu lingkungan fisik yang dibuat oleh kecerdasan komputer dengan maksud mempermudah pengguna untuk mengidentifikasi hubungan dengan lingkungan buatan yang mirip dengan lingkungan sebenarnya (Atoillah, 2019). Berikut merupakan contoh penggunaan Virtual Environment bagi keselamatan dan kesehatan kerja, diantaranya (Wilson, 1999):

a. Penilaian ergonomis lingkungan kerja meliputi perancangan tata letak ruang kerja.

b. Pelatihan umum untuk pekerja, seperti penerapan SOP penggunaan mesin.

c. Analisis kesalahan (error) dan perbaikan proses produksi pada perusahaan.

d. Pelatihan teknisi seperti untuk pekerja yang bekerja di lingkungan berbahaya.

Pembuatan lingkungan virtual ini perlu didukung oleh teknologi berupa software. Software yang dapat digunakan adalah software Siemens Human Tecnomatic Jack.

\section{Questionnaire Nordic Body Map}

Kuisioner Nordic Body Map adalah kuesioner yang dipakai untuk mendapatkan detail gangguan atau rasa sakit yang diterima tubuh saat bekerja yang dialami oleh pekerja, meskipun subjektif namun kuesioner ini cukup valid untuk digunakan dan telah terstandarisasi (Kroemer K, Kroemer H, Kroemer A, 2001). Sembilan bahan utama yang menjadi bahan dalam pembuatan kuesioner digambarkan pada tubuh manusia diantaranya (Kroemer K, Kroemer H, Kroemer A, 2001) :

\section{Leher}

2. Bahu

3. Punggung bagian atas

4. Siku

\section{Punggung bagian bawah}

\section{Pergelangan tangan/tangan}

7. Pantat

8. Lutut

9. Kaki

\section{Software Human Jack Simulation}

Software Siemens Tecnomatix Jack, merupakan salah satu software yang biasa digunakan untuk membuat lingkungan virtual. Ada beberapa tahapan yang perlu dilakukan sebelum melakukan simulasi, diantaranya (Löfqvist et al., 2012):

a) Buat objek yang menjadi bahan dalam pembuatan virtual environment menggunakan software CAD, kemudian masukan hasil rancangan CAD pada software Jack dan atur posisi sesuai kondisi lingkungan yang sebenarnya.

b) Membuat model manusia (manikins), melalui tools Advanced Human Scaling model manusia dapat dibuat sesuai ukuran antropometri yang diinginkan.

c) Posisikan model manusia pada lingkungan virtual yang telah dibuat sesuai dengan kondisi aktual yang diteliti.

d) Pemberian tugas pada model manusia yang telah dibuat, yaitu menunjukan mekanisme gerakan operasi suatu pekerjaan. 
e) Menganalisis hasil simulasi yang telah dibuat menggunakan bantuan tools TAT yang tersedia pada software.

\section{Posture Evaluation Index (PEI)}

Analisis PEI merupakan tools yang dikembangkan untuk menilai postur kerja dengan tepat melalui perhitungan pengintegrasian antara skor penilaian Lower Back Analysis (LBA), Ovako Working Posture Analysis (OWAS) dan Rapid Upper Limb Assesment (RULA), sehingga memudahkan untuk mendeteksi critical posture yang perlu diminimasi pekerja (Caputo et al., 2006 dalam Siahaan, 2012). Analisis PEI mengandalkan tools yang terdapat pada software Jack, yaitu Task Analysis Toolkits (TAT). Berikut merupakan alur penggunaan dari metode PEI dapat dilihat pada Gambar 1.

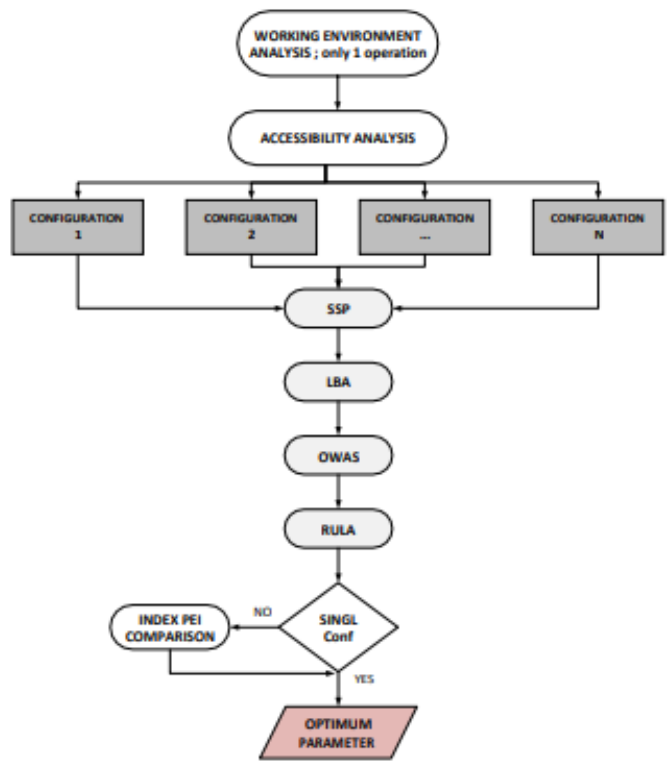

Gambar 1 Alur Penggunaan PEI (Caputo, Gironimo, Marzano, 2017)

Analisis PEI menggabungkan perhitungan dari ketiga metode sehingga diakumulasikan menjadi tiga variabel yaitu I1, I2, dan I3. Berikut keterangan dari ketiga variabel PEI:

Variabel I adalah perbandingan hasil skor yang didapatkan LBA dengan batas aman gaya tekan yang ditetapkan NIOSH yaitu 3400 Newton. Secara matematis nilai I1 dapat dihitung menggunakan rumus (I.1). Perlu dipastikan nilai I1 harus menujukan lebih kecil dari satu, apabila nilai didapatkan lebih dari 1 maka kegiatan yang disimulasikan belum valid.

$$
\mathrm{I} 1=\frac{L B A}{3400}
$$

Variabel $\mathbf{I 2}$ adalah perbandingan hasil akhir OWAS dan indeks nilai maksimum yaitu 4. Nilai I2 dihitung memakai rumus (I.2).

$$
\mathrm{I} 2=\frac{O W A S}{4}
$$

Variabel I3 adalah perbandingan hasil akhir RULA dengan nilai maksimum RULA yaitu 7. Secara matematis nilai I3 dihitung memakai rumus (I.3).

$$
\mathrm{I} 3=\frac{R U L A}{7}
$$

Tahapan selanjutnya, setalah mengetahui nilai setiap variabel, maka nilai PEI dapat dihitung dengan rumus (I.4).

$\mathrm{PEI}=\frac{L B A}{3400}+\frac{O W A S}{4}+\frac{R U L A}{7} \mathrm{mr}$

$$
\mathrm{PEI}=\mathrm{I} 1+\mathrm{I} 2+\mathrm{I} 3 \cdot \mathrm{mr}
$$

dengan:

$\mathrm{mr}=$ amplification factor yaitu 1,42 .

Keterangan: 
$3400 \mathrm{~N}=$ batas gaya tekan pada tulang punggung.

4 = nilai indeks maksimal analisis OWAS

$7=$ Nilai maksimal risiko tubuh bagian atas hasil analisis RULA.

$\mathrm{Mr}=$ koefisien amplifikasi nilai PEI

Diketahui nilai minimum PEI adalah 0,47 yaitu kondisi dimana operator tidak mendapat beban sama sekali, dan nilai maksimum PEI adalah 3,42 tergantung pada nilai I1 yang diasumsikan dengan nilai $\mathrm{I} 1 \geq 1$ adalah tidak valid. Dinyatakan semakin rendah nilai PEI maka semakin baik kenyamanan pekerja serta risiko kerja pun rendah. Sebaliknya, nilai PEI semakin tinggi maka tingkat kenyamanan pekerja semakin tidak baik dan risiko kerja dapat dikatakan tinggi.

\section{Hasil Penelitian dan Pembahasan}

Pengumpulan Data yang dibutuhkan meliputi data-data yang dibutuhkan dalam pemodelan virtual environment, diantaranya data tinggi dan berat badan operator, bentuk dan dimensi fasilitas kerja, serta gambaran postur dan operasi kerja operator di pengelompokan. Data keluhan juga dikumpulkan melalui penyebaran kuesioner nordic body map pada setiap operator di pengelompokan. Terdapat enam operator pada bagian proses pengelompokan. Proses kerja pengelompokan dibagi kedalam tiga proses diantaranya, pencatatan, pelabelan, dan pengelompokan. Proses kerja pengelompokan didukung oleh alat dan fasilitas diantaranya meja pencatatan, kursi, meja pelabelan, alat pelabelan, dan alat tulis. Rangkaian proses kerja di pengelompokan ditunjukkan pada Gambar 2.

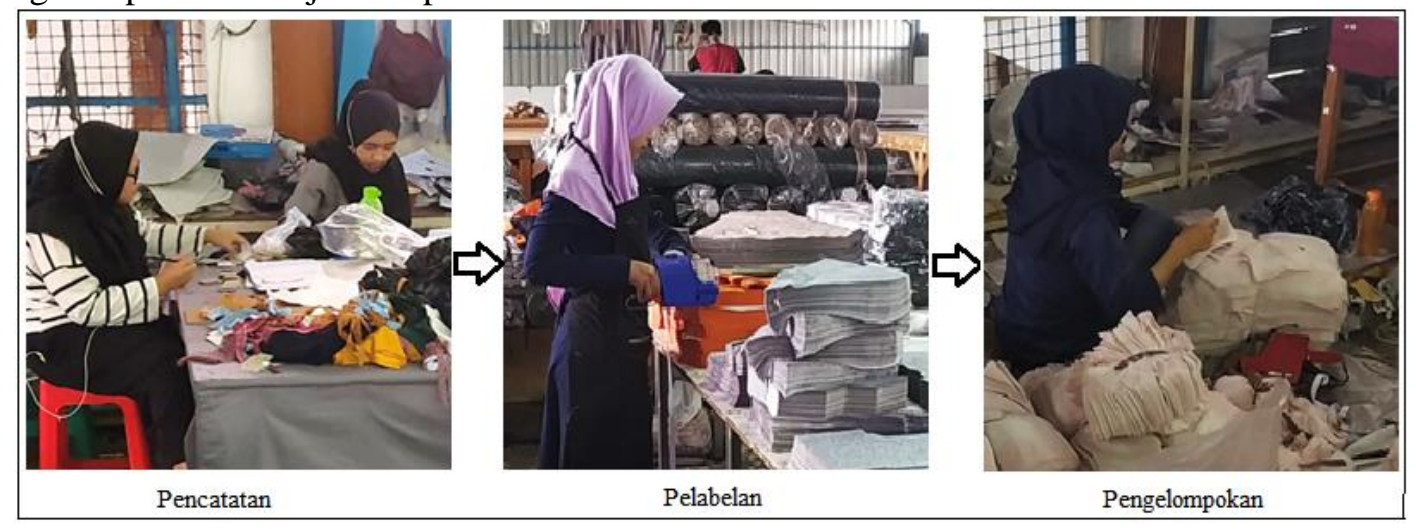

Gambar 2 Rangkaian Proses Kerja Pengelompokan

Penyebaran kuesioner nordic body map mengumpulkan data meliputi data keluhan, data penilaian rasa sakit, dan informasi mengenai rasa sakit yang dialami. Rekapitulasi hasil pengumpulan kuesioner ditunjukkan pada Tabel 1.

Tabel 1. Rekapitulasi Data Keluhan Operator Pengelompokan

\begin{tabular}{|c|c|c|c|c|c|}
\hline Operator & $\begin{array}{l}\text { Dalam } 12 \text { bulan terakhir memiliki } \\
\text { masalah bagian tubuh }\end{array}$ & $\begin{array}{c}\text { Selama } 12 \text { bulan } \\
\text { terakhir terhalang } \\
\text { menjalankan } \\
\text { aktivitas normal }\end{array}$ & $\begin{array}{l}\text { Dalam } 7 \text { hari } \\
\text { terakhir } \\
\text { memiliki rasa } \\
\text { nyeri }\end{array}$ & $\begin{array}{l}\text { Penilaian } \\
\text { rasa sakit }\end{array}$ & $\begin{array}{c}\text { Pernah menemui } \\
\text { terapis atau dokter } \\
\text { untuk mengobati } \\
\text { sakit pada bagian } \\
\text { tubuh }\end{array}$ \\
\hline \multirow{4}{*}{1} & Leher & Tidak pernah & Tidak pernah & 3 & Tidak pernah \\
\hline & Punggung Bawah & Tidak pernah & Tidak pernah & 6 & Tidak pernah \\
\hline & Pergelangan tangan (kanan \& kiri) & Tidak pernah & Tidak pernah & 1 & Tidak pernah \\
\hline & Bokong/paha & Tidak pernah & Tidak pernah & 6 & Tidak pernah \\
\hline \multirow{4}{*}{2} & Leher & Tidak pernah & Tidak pernah & 3 & Tidak pernah \\
\hline & Punggung Bawah & Tidak pernah & Tidak pernah & 6 & Tidak pernah \\
\hline & Pergelangan tangan (kanan \& kiri) & Tidak pernah & Tidak pernah & 3 & Tidak pernah \\
\hline & Bokong/paha & Tidak pernah & Tidak pernah & 2 & Tidak pernah \\
\hline \multirow{4}{*}{3} & Leher & Tidak pernah & Tidak pernah & 3 & Tidak pernah \\
\hline & Punggung Bawah & Tidak pernah & Tidak pernah & 6 & Tidak pernah \\
\hline & Pergelangan tangan (kanan \& kiri) & Tidak pernah & Tidak pernah & 1 & Tidak pernah \\
\hline & Bokong/paha & Tidak pernah & Tidak pernah & 6 & Tidak pernah \\
\hline
\end{tabular}


Lanjutan Tabel 2. Rekapitulasi Data Keluhan Operator Pengelompokan

\begin{tabular}{|c|c|c|c|c|c|}
\hline Operator & $\begin{array}{l}\text { Dalam } 12 \text { bulan terakhir memiliki } \\
\text { masalah bagian tubuh }\end{array}$ & $\begin{array}{l}\text { Selama } 12 \text { bulan } \\
\text { terakhir terhalang } \\
\text { menjalankan } \\
\text { aktivitas normal }\end{array}$ & $\begin{array}{l}\text { Dalam } 7 \text { hari } \\
\text { terakhir } \\
\text { memiliki rasa } \\
\text { nyeri }\end{array}$ & $\begin{array}{l}\text { Penilaian } \\
\text { rasa sakit }\end{array}$ & $\begin{array}{l}\text { Pernah menemui } \\
\text { terapis atau dokter } \\
\text { untuk mengobati } \\
\text { sakit pada bagian } \\
\text { tubuh }\end{array}$ \\
\hline \multirow{3}{*}{4} & Leher & Tidak pernah & Tidak pernah & 2 & Tidak pernah \\
\hline & Punggung Bawah & Tidak pernah & Tidak pernah & 6 & Tidak pernah \\
\hline & Bokong/paha & Tidak pernah & Tidak pernah & 6 & Tidak pernah \\
\hline \multirow{3}{*}{5} & Leher & Tidak pernah & Tidak pernah & 1 & Tidak pernah \\
\hline & Punggung Bawah & Tidak pernah & Tidak pernah & 6 & Tidak pernah \\
\hline & Bokong/paha & Tidak pernah & Tidak pernah & 5 & Tidak pernah \\
\hline \multirow{2}{*}{6} & Punggung Bawah & Tidak pernah & Tidak pernah & 6 & Tidak pernah \\
\hline & Bokong/paha & Tidak pernah & Tidak pernah & 6 & Tidak pernah \\
\hline
\end{tabular}

Pengolahan data di mulai dari pembuatan virtual environment stasiun kerja persiapan bagian pengelompokan menggunakan software Jack Human Simulation. Pembuatan model aktual memiliki tahapan diantaranya, pembuatan objek 3D menggunakan software AutoCad, pembuatan lingkungan virtual, pembuatan model manusia, dan memposisikan model manusia. Lingkungan virtual stasiun kerja persiapan bagian pengelompokan ditunjukkan pada Gambar 3.

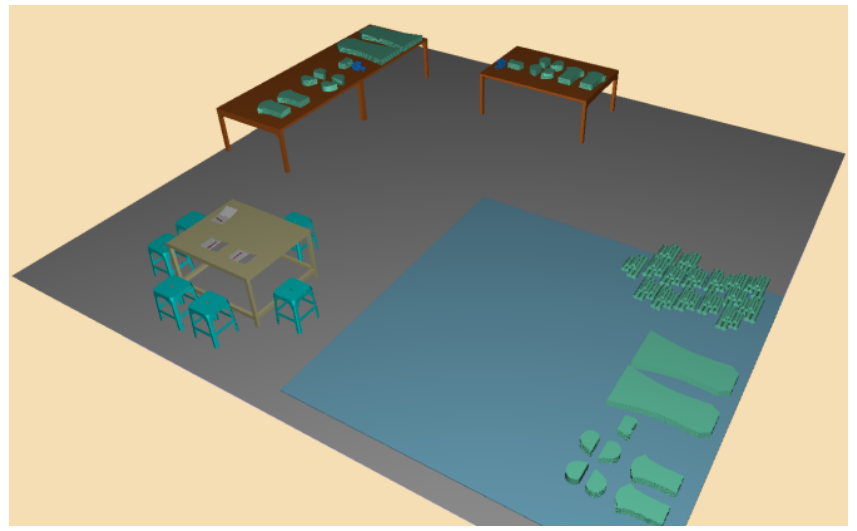

Gambar 3. Lingkungan Virtual Model Aktual

Selanjutnya dilakukan simulasi pemodelan proses kerja aktual diperusahaan. Pemodelan dibagi kedalam tiga rangkaian proses, yaitu pencatatan, pelabelan, dan pengelompokan. Pemodelan rangkaian proses pada pengelompokan ditunjukkan pada Gambar 4.

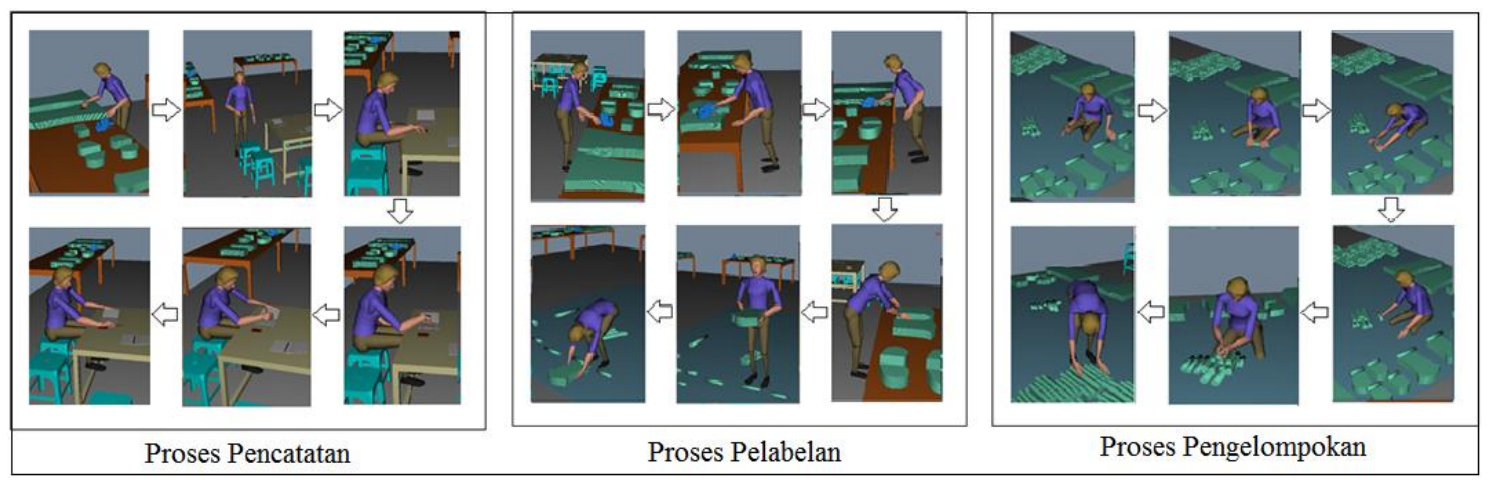

Gambar 4. Rangkaian Proses Kerja Pengelompokan

Pemodelan dilakukan agar risiko dapat diukur pada setiap postur aktivitas di pengelompokan. Pengukuran risiko pada software meliputi perhitungan risiko LBA, OWAS, RULA dan analisis Statis Strength Prediction (SSP). Analisis SSP diperlukan untuk mengetahui seberapa persen kapabilitas model operator yang telah dibuat dapat dilakukan oleh populasi pekerja lain. Ditetapkan batas $90 \%$ sebagai persyaratan model dapat dilanjutkan untuk 
pengukuran risiko kerja. Didapatkan persentase $>90 \%$ untuk seluruh model aktivitas yang telah dibuat, sehingga dapat dilanjutkan pada pengukuran risiko kerja selanjutnya. Berdasarkan pengukuran dari ketiga risiko, kemudian dilakukan perhitungan PEI. Rekapitulasi hasil perhitungan PEI pada ketiga proses ditunjukkan pada Tabel 2.

Tabel 3 Rekapitulasi Hasil Pehitungan PEI Proses Pencatatan

\begin{tabular}{|l|c|c|c|c|c|}
\hline \multirow{2}{*}{\multicolumn{1}{|c|}{ Proses }} & \multicolumn{5}{|c|}{ Nilai Rentang Pada Setiap Postur Aktivitas } \\
\cline { 2 - 6 } & SSP & LBA (Newton) & OWAS & RULA & PEI \\
\hline Pencatatan & $>90 \%$ & $349-950$ & $1-2$ & $2-3$ & $0,87-1,73$ \\
\hline Pelabelan & $>90 \%$ & $267-1430$ & $1-3$ & $2-7$ & $0,87-3,01$ \\
\hline Pengelompokan & $>90 \%$ & $766-1525$ & $1-3$ & $6-7$ & $2,25-3$ \\
\hline
\end{tabular}

Berdasarkan hasil penilaian risiko, nilai PEI 2,25 - 3,01 pada setiap postur aktivitas dapat dikategorikan tinggi dikarenakan mendekati nilai maksimum PEI yaitu 3,42 dan dinilai berisiko bagi operator. Nilai tersebut dipengaruhi oleh nilai skor RULA yang cukup tinggi yaitu pada rentang $5-7$ yang mengindikasikan perlu segera dilakukan perbaikan. Postur aktivitas yang berisiko tersebut adalah pemindahan hasil pelabelan, aktivitas proses pengelompokan, dan aktivitas proses pemindahan hasil akhir pengelompokan yang dinilai memiliki postur berisiko pada operator.

Perancangan Fasilitas berupa meja pengelompokan beserta tempat hasil penyimpanan pengelompokan. Perancangan dilakukan untuk dapat menghilangkan postur aktivitas yang dinilai berisiko bagi operator. Perancangan dilakukan menggunakan pendekatan antropometri agar perancangan lebih ergonomis. Dimensi tubuh yang dipakai dalam pembuatan perancangan diantaranya Tinggi Siku Berdiri (TSB), Panjang Rentang Tangan (RT), Jangkauan Tangan ke Depan (JTD), dan Tangan ke Lantai (TL). Perancangan fasilitas ergonomis ditunjukkan pada Gambar 5.

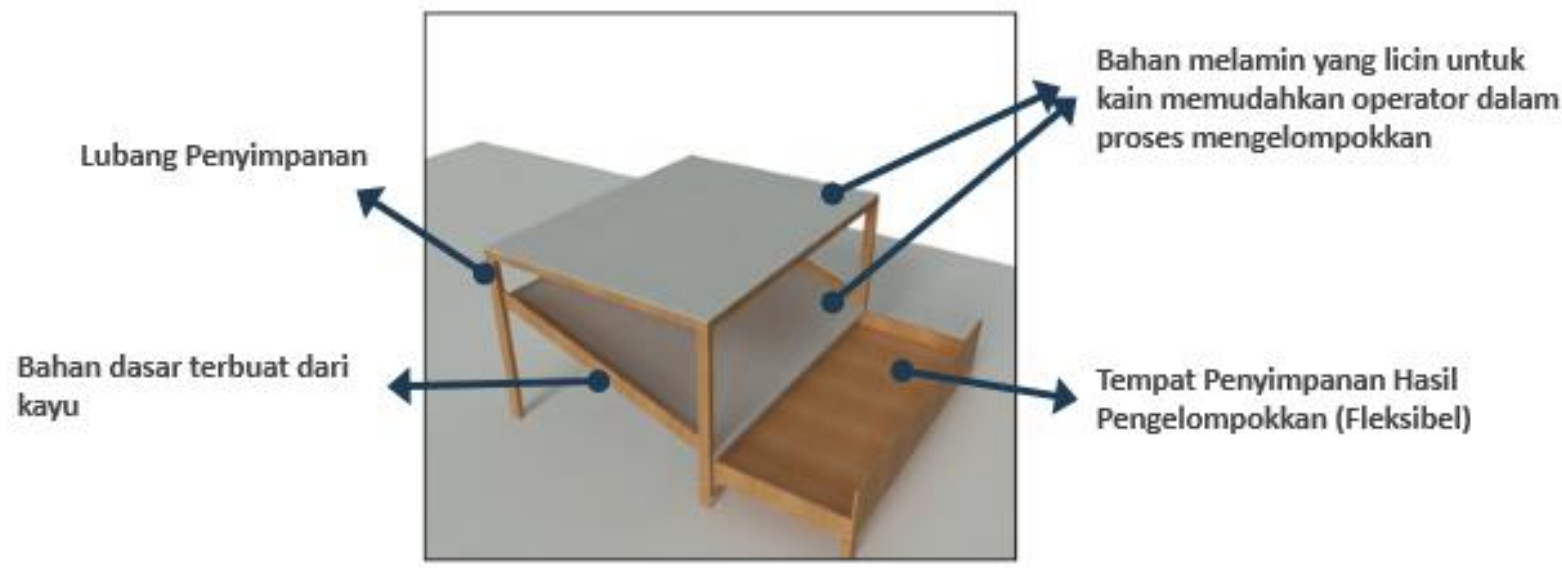

Gambar 5. Fasilitas Kerja Meja Ergonomis

Fasilitas ergonomis yang telah dirancang selanjutnya dimodelkan kembali sehingga didapatkan model ergonomis hasil dari pemodelan virtual environment. Stasiun kerja ergonomis hasil perancangan ditunjukkan pada Gambar 6. 


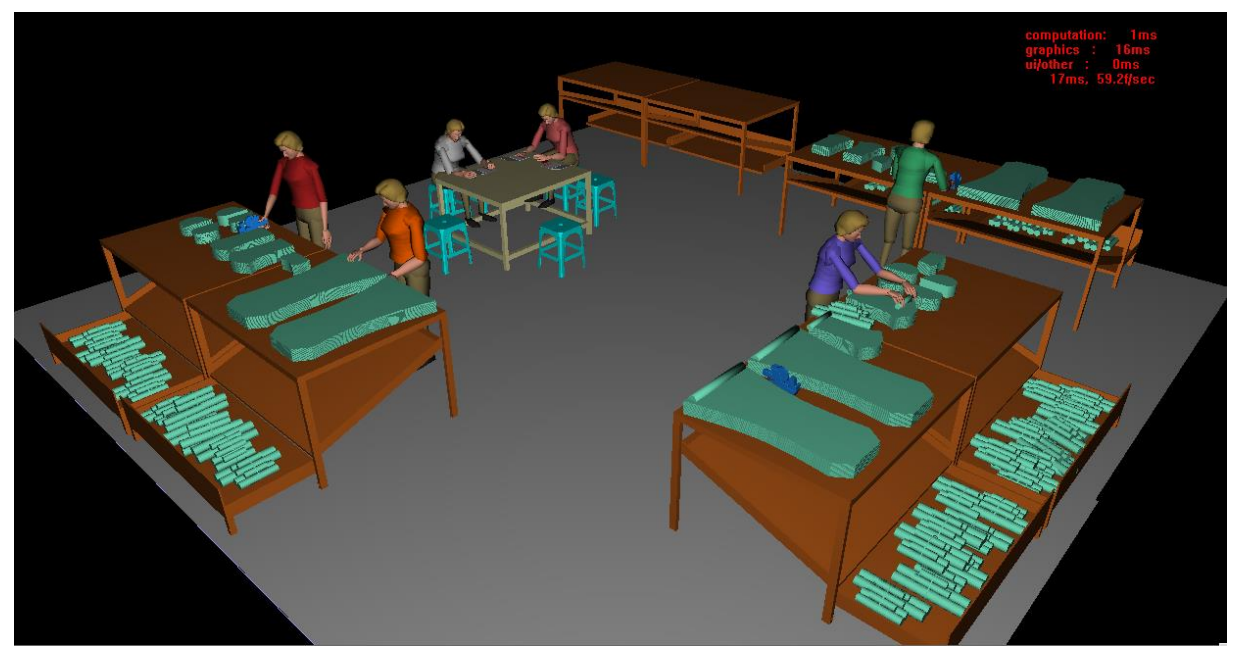

Gambar 6. Stasiun kerja ergonomis hasil perancangan

Virtual environment yang telah dibuat selanjutnya dimodelkan kembali sehingga didapatkan rangkaian proses kerja baru untuk diukur kembali risiko kerja hasil perancangan fasilitas ergonomis. Rangkaian proses kerja ergonomis ditunjukkan pada Gambar 7.
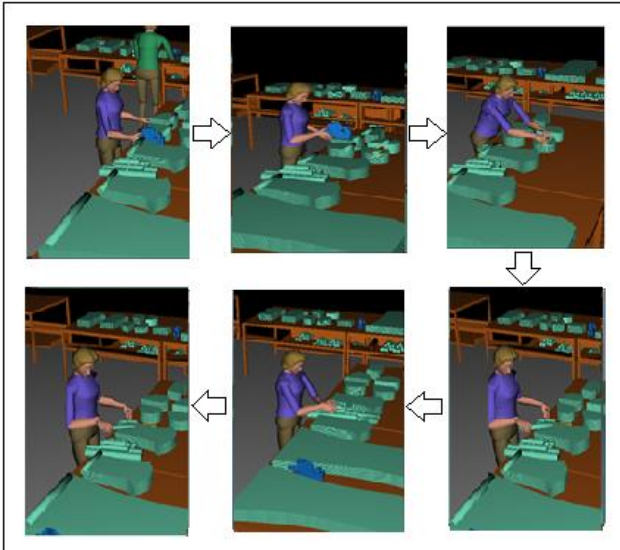

Gambar 7. Rangkaian Proses Kerja Hasil Perancangan

Pengukuran risiko kerja dilakukan pada rangkaian proses kerja hasil perancangan. Rekapitulasi hasil pengukuran pada rangkaian proses ergonomis ditunjukkan pada Tabel 3.

Tabel 4. Rekapitulasi Hasil Pehitungan PEI Proses Ergonomis

\begin{tabular}{|c|c|c|c|c|c|}
\hline \multirow{2}{*}{ Proses } & \multicolumn{5}{|c|}{ Nilai Rentang Pada Setiap Postur Aktivitas } \\
\cline { 2 - 6 } & SSP & LBA (Newton) & OWAS & RULA & PEI \\
\hline Pengelompokan Ergonomis & $>90 \%$ & $323-789$ & $1-2$ & $2-3$ & $0,97-1,65$ \\
\hline
\end{tabular}

Nilai skor PEI pada proses pengelompokan hasil perancangan untuk seluruh operator memiliki nilai rentang nilai $1-1,63$. Berdasarkan range nilai PEI $0,47-3,42$, nilai tersebut dapat dikatakan masuk kedalam kategori minimum. Berdasarkan hasil pengukuran risiko aktual dan ergonomis, terdapat Terdapat perubahan tingkat risiko dilihat dari perubahan nilai PEI aktual yang mencapai rentang 2,25-3,01 menjadi 0,97-1,65 PEI Ergonomis. Perancangan fasilitas ergonomis yang dilakukan dapat meminimasi nilai PEI. Hal tersebut menunjukkan bahwa perancangan fasilitas dapat mengurangi risiko pekerjaan dan membuat operator lebih nyaman dalam melakukan pekerjaan. 


\section{Kesimpulan}

Berdasarkan pembahasan dalam penelitian ini, peneliti menyimpulkan beberapa hasil penelitian sebagai berikut:

1. Berdasarkan hasil penyebaran kuesioner nordic body map, diketahui bagian tubuh yang dikeluhkan operator diantaranya Leher, Pergelangan tangan, Punggung bawah, dan Bokong/paha.

2. Hasil penilaian risiko kerja saat ini menunjukkan bahwa postur pada aktivitas pemindahan komponen hasil pelabelan, proses pengelompokan, dan pemindahan hasil akhir menimbulkan risiko pekerjaan pada operator sehingga perlu dilakukan perbaikan. Nilai PEI aktual yang dinilai berisiko mencapai rentang nilai 2,25 - 3,01 dan nilai tersebut mendekati nilai maksimum PEI yaitu 3,42.

3. Perancangan fasilitas kerja yang dibuat berupa meja pengelompokan dengan tempat penyimpanan yang fleksibel. Perancangan meja dilakukan menggunakan pendekatan antropometri sehingga lebih ergonomis dan memberikan kenyamanan pada operator pengelompokan. Perancangan meja ergonomis ini menghilangkan aktivitas yang dinilai berisiko pada operator. Model ergonomis yang dirancang dapat mengurangi nilai PEI menjadi pada rentang nilai $0,97-1,65$. Nilai tersebut dikategorikan rendah karena mendekati nilai minimum yaitu 0,47 . Maka dapat disimpulkan bahwa perancangan fasilitas ergonomis yang dibuat dapat mengurangi risiko kerja operator dan menambah kenyamanan operator dalam melakukan pekerjaan pengelompokan.

\section{Acknowledge}

Puji Sukur kepada Allah SWT, penelitian ini dapat terselesaikan sesuai dengan harapan. Peneliti ucapkan terimakasih kepada orang tua dan keluarga yang tiada hentinya mendukung proses penelitian, kepada dosen pembimbing yang senantiasa membimbing dalam proses penyusunan laporan, juga $\mathrm{CV}$. X yanng telah memberikan izin serta akses penelitian di perusahaan.

\section{Daftar Pustaka}

[1] Bioenergi Center. 2016. Meningkatkan Produktivitas Perusahaan \& Efisiensi SDM. [online] Yogyakarta. Tersedia pada: <https://bioenergicenter.com/> [diakses 17 Juni 2020].

[2] Caputo, F., Gironimo, G. Di, \& Marzano, A. 2006. Ergonomic Optimization of a Manufacturing System Work Cell in a Virtual Environment. Ergonomic Optimization of a Manufacturing System Work Cell in a Virtual Environment, 46(5), 21-27. https://doi.org/10.14311/872

[3] Dragcevic, Z., Zavec, D., Rogale, D., \& Gersak, J. 2002. Workload and Standard Time Norms in Garment Engineering. Spring, 2(2), 1-11.

[4] Kroemer, K.H.E., Kroemer, H.B., and Kroemer-Elbert, K.E., 2001, "Ergonomics: How to Design for Ease \& Efficiency", Prentice-Hall Inc., New Jersey

[5] Löfqvist, L., dkk. 2012. Ergonomic evaluation of long-shafted tools used in horse stables: the effects of shaft length variation and work technique on working posture. International Journal of Human Factors and Ergonomics, 1(3), 298. https://doi.org/10.1504/ijhfe.2012.050872

[6] Pradnyawati, M. A., Tunas, I. K., \& Natalia Yudha, N. L. G. A. 2017. Intervensi Sikap Kerja Dapat Menurunkan Kelelahan Kerja Dan Keluhan Muskuloskeletal Pada Karyawan Pt. Sucofindo Cabang Denpasar. Jurnal Kesehatan Terpadu, 1(1), 30-37. https://doi.org/10.36002/jkt.v1i1.160

[7] Tamara, Achiraeniwati, \& Rezeki. 2018. Perancangan Fasilitas Kerja Ergonomis pada Stasiun Kerja Pengeleman untuk Mengurangi Resiko Musculoskeletal Disorders (MSDs). Prosiding Teknik Industri UNISBA. 4 (2).

[8] Tarwaka. 2015. Ergonomi Industri Dasar-Dasar Pengetahuan Ergonomi dan Aplikasi di Tempat Kerja . Solo: Harapan Press Solo.

[9] Wignjosoebroto, S. 2006. Teknik Analisis Untuk Peningkatan Produktivitas Kerja. Surabaya: Guna Widya. 
130 Ade Hilman Fajar, et al.

[10] Wilson, J. R. 1999. Virtual environments applications and applied ergonomics. Applied Ergonomics, 30(1), 3-9. https://doi.org/10.1016/S0003-6870(98)00040-4 